Click www.researchjournal.co.in/online/subdetail.html to purchase.

INTERNATIONAL JOURNAL OF PLANT PROTECTION

- ISSN-0974-2670 | Visit us : www.researchjournal.co.in

\title{
Management of purple blotch of onion caused by Alternaria porri by using some novel fungicides under field condition in western Odisha
}

\author{
Dipankar Mandal*, Rini Pal and Ashok Kumar Mohanty
}

Regional Research and Technology Transfer Station, Odisha University of Agriculture and Technology, Chiplima, Sambalpur (Odisha) India (Email: rinipatho@gmail.com;drakmohanty1962@gmail.com)

\section{ARITCLE INFO}

Received : 28.07 .2020

Revised : 10.09 .2020

Accepted : 24.09 .2020

KEY WORDS :

Onion, Purple blotch, Fungicides

*Corresponding author:

Email : dipankarpatho@gmail.com

\begin{abstract}
A field experiment was conducted at Regional Research and Technology Transfer Station, OUAT, Chiplima, Sambalpur, Odisha, India for the management of purple blotch of onion. From the experiment it was found that all the treatments were effective to reduce the severity of the disease as compared to untreated control. Among the treatments, seed treated with Carboxin 37.5\%+Thiram 37.5\%@2g/kg and three foliar sprays of Trifloxystrobin + Tebuconazole @ $0.4 \mathrm{~g} / 1$ of water at 10 days interval starting from initiation of the disease was most effective in reducing the purple blotch disease of onion ( $69.5 \%$ disease control) and was closely followed by seed treated with Carboxin 37.5\%+Thiram 37.5\%@ @ g/kg and three foliar sprays of Tebuconazole @ 1.0ml $/ 1$ of water (62.3\% disease control). A maximum increase of yield (83.4\%) with highest cost benefit ratio (1.97) was also achieved with the same treatment.
\end{abstract}

How to view point the article : Mandal, Dipankar, Pal, Rini and Mohanty, Ashok Kumar (2020). Management of purple blotch of onion caused by Alternaria porri by using some novel fungicides under field condition in western Odisha. Internat. J. Plant Protec., 13(2) : 187-191, DOI : 10.15740/HAS/IJPP/13.2/187-191, Copyright@ 2020: Hind Agri-Horticultural Society. 